\title{
De invloed van werkeisen en hulpbronnen op uitputting en bevlogenheid
}

\author{
Joris Van Ruysseveldt, Peter Smulders en John Taverniers*
}

\begin{abstract}
De kosten van psychosociale arbeidsbelasting zijn in Nederland op 4 miljard euro per jaar geschat. Een goed inzicht in de werkkenmerken die uitputting en bevlogenheid, en daarmee samenhangend: arbeidsongeschiktheid, ziekteverzuim en verloop, beïnvloeden, is daarmee zowel theoretisch als beleidsmatig relevant. In dit onderzoek zijn een additieve toetsing (met alleen hoofdeffecten) en een multiplicatieve toetsing (met interacties tussen alle werkkenmerken) uitgevoerd van het Job Demands-Resources-model (JD-R-model) op een omvangrijke, representatieve steekproef uit de Nederlandse beroepsbevolking (TNO Arbeidssituatie Survey, TAS 2002). De onderzochte werkeisen - werkdruk, emotionele belasting, fysieke belasting, WTI en taakcomplexiteit - hebben een significant positief hoofdeffect en de hulpbronnen - autonomie, ontwikkelingsmogelijkheden, werkzekerheid en steun van leiding en collega's - hebben een significant negatief hoofdeffect op uitputting. De hulpbronnen hebben een significant hoofdeffect op de bevlogenheid, maar de werkeisen niet. Bovendien heeft taakcomplexiteit - in tegenspraak met de verwachtingen een significant positief effect op bevlogenheid. Uit het onderzoek kan niet worden afgeleid dat het multiplicatieve model een duidelijke meerwaarde heeft boven het eenvoudiger additieve model. Er worden - zowel bij uitputting als bij bevlogenheid - slechts enkele significante dempende (bufferende) interactie-effecten gevonden. Wel blijken ook enkele interacties tussen werkeisen onderling en tussen hulpbronnen onderling significant (de zogenoemde versterkingshypothese).
\end{abstract}

Trefwoorden: JD-R-model, autonomie, bufferhypothese, TNO Arbeidssituatie Survey (TAS) 2002

\section{Inleiding}

In dit onderzoek willen we nagaan in welke mate verschillen in emotionele uitputting en bevlogenheid tussen Nederlandse werknemers te verklaren zijn op basis van tien werkkenmerken, zoals dat eerder al is gedaan voor Vlaamse werknemers (Van Ruysseveldt, 2006). Het onderzoek is gebaseerd op het Job Demands-Resources-model (JD-Rmodel) (Demerouti, Nachreiner, Bakker \& Schaufeli, 2001). Meer specifiek voeren we twee toetsingen van dat model uit. De eerste betreft een strikt additieve toetsing. De veronderstelling daarbij luidt dat de werkkenmerken alleen hoofdeffecten hebben op de beide afhankelijke variabelen. De tweede betreft een multiplicatieve toetsing: naast de hoofdeffecten zijn in dit model ook alle interactietermen tussen de werkkenmerken opgenomen.

Joris Van Ruysseveldt is werkzaam bij de Open Universiteit Nederland. Correspondentieadres: Open Universiteit Nederland, Faculteit Psychologie, Postbus 2960, 6401 DL Heerlen, e-mail: joris.vanruysseveldt@ou.nl.

Peter Smulders is werkzaam bij TNO Kwaliteit van Leven.

John Taveniers is werkzaam bij de Open Universiteit Nederland en de Koninklijke Militaire School te Brussel. 
Een goed vergelijkbaar onderzoek op een omvangrijke steekproef uit de Vlaamse beroepsbevolking is eerder al in dit tijdschrift gerapporteerd (Van Ruysseveldt, 2006). De resultaten bevestigen dat naarmate de werkdruk, emotionele belasting, belastende arbeidsomstandigheden, WTI en werkonzekerheid toenemen, de psychische vermoeidheid stijgt en het plezier in het werk daalt. Naarmate de werknemer over meer zelfstandigheid, steun van de leidinggevende en leermogelijkheden beschikt, daalt de psychische vermoeidheid en stijgt het plezier in het werk. Voor de bufferhypothese (zie hierna) leverden de onderzoeksresultaten slechts gedeeltelijk steun.

\section{Onderzoeksvragen, theoretische en praktische relevantie}

Onze centrale onderzoeksvraag is in welke mate de additieve en multiplicatieve 'varianten' van het JD-R-model in staat zijn verschillen in emotionele uitputting en bevlogenheid tussen Nederlandse werknemers te verklaren. En heeft de multiplicatieve variant daarbij een meerwaarde boven het additieve model?

De kosten van psychosociale arbeidsbelasting zijn geschat op 4 miljard euro per jaar (Blatter, Houtman, Van den Bossche, Kraan \& Van den Heuvel, 2005). Deze schatting omvat alle kosten die samenhangen met ziekteverzuim, arbeidsongeschiktheid, ziekenhuisopname en zelfs sterfte. Uit onderzoek van Schaufeli \& Bakker (2004: 293) is bekend dat emotionele uitputting samenhangt met een slechtere gezondheidstoestand en met een hogere verloopgeneigdheid. Bevlogenheid leidt tot een lagere verloopgeneigdheid. Bovendien medieert emotionele uitputting het verband tussen te hoge werkeisen en een slechte gezondheidstoestand. Bevlogenheid medieert het verband tussen de hulpbronnen en verloopgeneigdheid. Om arbeidsongeschiktheid, ziekteverzuim, verloop en dergelijke effectief terug te dringen, dienen we bijgevolg een goede kijk te krijgen op de mechanismen die ten grondslag liggen aan het ontstaan van uitputting en bevlogenheid.

In onderzoek van Smulders (2008) is gevonden dat de werkdruk in Nederland hoog is, hoewel er de laatste jaren sprake is van enige stabilisatie. Hoewel een te hoge werkdruk een belangrijke stressbron is (zie bijvoorbeeld Van Ruysseveldt, 2006), is het in beleidsmatig opzicht relevant gefundeerde kennis op te bouwen over de mogelijke invloed van andere werkkenmerken. Modeltoetsend onderzoek zoals in dit artikel wordt beschreven, is in die zin beleidsmatig relevant dat een beter en vooral completer inzicht mogelijk wordt in de factoren die invloed hebben op het ontstaan van werkgerelateerde problemen bij werknemers; het laat daardoor toe effectievere interventies en preventiemaatregelen uit te werken, bijvoorbeeld met het oog op het terugdringen van ziekteverzuim of verloop.

We willen met dit onderzoek dus achterhalen welke werkkenmerken significante voorspellers zijn van zowel emotionele uitputting als van bevlogenheid bij werknemers. Bij onze toetsingen gebruiken we een representatieve steekproef uit de Nederlandse beroepsbevolking. We maken gebruik van de data verzameld in het kader van de TNO Arbeidssituatie Survey (TAS) uit 2002 (Smulders, Andries \& Otten, 2001). Doorgaans zijn stressmodellen zoals het Job Demands-Control-model (JD-C-model) van Karasek (Karasek \& Theorell, 1990) of het JD-R-model toegepast op minder omvangrijke en homogeen samengestelde steekproeven (zie Demerouti et al., 2001; Schaufeli \& Bakker, 2004; Van Ruysseveldt, Cambré, Depickere \& Adiele, 2004; Bakker, Demerouti \& Eu- 
wema, 2005; Bakker \& Demerouti, 2007). Omvangrijke en heterogene steekproeven, zoals de TAS, lenen zich echter beter voor modeltoetsing, en in het bijzonder voor het toetsen van interactie-effecten.

De uitgevoerde multiplicatieve toetsing is in theoretisch opzicht nog bijkomend relevant. In het model zijn namelijk interacties tussen alle werkkenmerken opgenomen, dus niet alleen tussen werkeisen en hulpbronnen (de bufferhypothese). Naast de bufferhypothese toetsen we ook wat we de versterkingshypothese noemen: deze omvat de interacties tussen werkeisen onderling en tussen hulpbronnen onderling (Van Ruysseveldt, 2006: 340-341). De veronderstelling luidt dat wanneer bepaalde werkeisen tezelfdertijd in hoge mate voorkomen, het effect ervan hoger ligt dan de optelsom van de afzonderlijke hoofdeffecten. Dezelfde veronderstelling geldt ten aanzien van de hulpbronnen. In de volgende paragraaf beschrijven we eerst kort de assumpties van het JD-R-model waarop ons onderzoeksmodel is gebaseerd.

\section{Het Job Demands-Resources-model (JD-R-model)}

Het JD-R-model (Bakker, Schaufeli \& Demerouti, 1999; Demerouti et al., 2001) gaat er ten eerste van uit dat, hoewel elke beroepsgroep wordt geconfronteerd met specifieke, beroeps- of functie-eigen taakkenmerken en risicofactoren, deze taakkenmerken en risicofactoren toch steeds onder te brengen zijn in twee brede categorieën. Job Demands of werkeisen omvatten alle fysieke, sociale of organisationele aspecten van het werk die een volgehouden fysieke of mentale inspanning vereisen en die om die reden verbonden zijn met specifieke fysiologische en psychologische kosten voor de werknemer (bijvoorbeeld uitputting). Job Resources of hulpbronnen omvatten alle fysieke, psychologische, sociale of organisationele aspecten van het werk die (a) bijdragen aan het realiseren van de taakdoelstellingen, (b) de fysiologische en psychologische kosten verbonden met de aanwezige werkeisen reduceren, en (c) persoonlijke groei en ontwikkeling stimuleren (Demerouti et al., 2001).

Ten tweede hangen werkeisen en hulpbronnen elk samen met specifieke uitkomsten, en dat als gevolg van het optreden van twee parallelle processen (Schaufeli \& Bakker, 2004: 297-299). In het energetische proces leiden de veeleisende aspecten van het werk tot een voortdurende aantasting van de energiereserves van de taakuitvoerder, en daarmee op de lange duur tot chronische vermoeidheid en uitputting. Het tweede proces is motivationeel van aard: hulpbronnen, zoals zelfstandigheid in het werk, kunnen intrinsiek motiveren doordat ze de werknemer in staat stellen diens behoeften aan persoonlijke groei en ontwikkeling te stimuleren en te realiseren. Maar ze spelen daarnaast ook een extrinsiek motiverende rol omdat ze het de werknemer mogelijk maken zijn taakdoelstellingen te realiseren. Dit tweede proces leidt tot een positieve psychische toestand bij de werknemer die bevlogenheid wordt genoemd.

Ten derde veronderstelt het JD-R-model dat allerlei werkeisen en hulpbronnen kunnen interacteren en zo tot verminderde uitputting en verhoogde motivatie leiden. De aanwezigheid van hulpbronnen buffert of dempt het negatieve effect van de werkeisen op uitputting, en omgekeerd kunnen werkeisen het positieve effect van hulpbronnen op motivatie en bevlogenheid ondermijnen. 
Het JD-R-model is meermaals in empirisch onderzoek getoetst (zie Demerouti et al., 2001; Schaufeli \& Bakker, 2004; Bakker et al., 2005; Bakker \& Demerouti, 2007). Zo vinden Demerouti et al. (2001) in drie onderscheiden beroepsgroepen - dienstverlening, industrie en transport - dat de aanwezigheid van veel werkeisen (werkdruk, tijdsdruk, belastende arbeidsomstandigheden en ploegenarbeid) bij de werknemer leidt tot uitputting. Wanneer de werknemer over te weinig hulpbronnen (feedback, beloning, autonomie, inspraak, werkzekerheid en steun van de leidinggevende) beschikt, leidt dat tot mentale distantie. Werknemers die met hoge werkeisen worden geconfronteerd, terwijl ze over weinig hulpbronnen beschikken, ontwikkelen zowel uitputtings- als mentale distantieverschijnselen. Op basis van een bestudering van het veelvuldige onderzoek in de JD-R-traditie besluiten Bakker \& Demerouti (2007: 317) dat werkeisen vooral een hoofdrol spelen in de aantasting van de energiereserves en dus in het ontstaan van uitputting en gezondheidsklachten. Hulpbronnen spelen een hoofdrol in het bevorderen van bevlogenheid, tevredenheid en motivatie. Ook een onderzoek op een representatieve steekproef uit de Vlaamse beroepsbevolking bevestigt de kernassumpties van het JD-R-model (Van Ruysseveldt, 2006). Uit een grootschalig onderzoek onder Nederlandse werknemers besluiten van Veldhoven, Taris, de Jonge en Broersen (2005) dat het JD-R-model een betere weerspiegeling van de werkelijkheid biedt dan het JD-C-model van Karasek (Karasek \& Theorell, 1990).

Ook met betrekking tot de bufferende werking van hulpbronnen op de relatie tussen werkeisen en werkuitkomsten is empirische evidentie beschikbaar (Bakker \& Demerouti, 2007: 322). In een onderzoek onder docenten uit het hoger onderwijs testen Bakker et al. (2005) de hypothese dat burn-out het resultaat is van het uit balans zijn van werkeisen en hulpbronnen. Van de 32 theoretisch mogelijke blijken 18 interactieeffecten significant. De onderzoeksresultaten leveren empirische evidentie voor de bufferhypothese, maar tonen tegelijk aan dat de bufferende werking van de hulpbronnen niet in alle theoretisch mogelijke gevallen wordt gevonden. In een onderzoek onder Vlaamse werknemers (Van Ruysseveldt, 2006) blijken bij de afhankelijke variabele psychische vermoeidheid slechts drie van de vijftien veronderstelde interactie-effecten significant. Bij de afhankelijke variabele plezier in het werk was dat in acht van de vijftien veronderstelde interactie-effecten het geval. Xanthopoulou, Bakker, Dollard, Demerouti, Schaufeli, Taris \& Schreurs (2007) vinden in een onderzoek in de Nederlandse thuiszorg op basis van moderated structural equational modeling steun voor 21 van de 32 veronderstelde interactie-effecten $(=66 \%)$. De onderzochte hulpbronnen blijken een sterkere buffer te vormen in de relatie tussen emotionele belasting/patiëntenwangedrag en uitputting, dan in de relatie tussen werkdruk/fysieke belasting en uitputting.

In een recent artikel onderstrepen Bakker \& Demerouti (2007) het belang van verder onderzoek naar de bufferende werking van hulpbronnen op de relatie tussen werkeisen en werkuitkomsten. Ze stellen dat onderzoekers daaraan te weinig aandacht hebben besteed omdat dergelijke interactie-effecten veel minder gemakkelijk empirisch op te sporen zijn dan hoofdeffecten. Dat laatste geldt in het bijzonder voor minder omvangrijke, homogene steekproeven (zie McClelland \& Judd, 1993). In dit onderzoek is gebruikgemaakt van een grootschalige en heterogeen samengestelde steekproef. Dergelijke steekproeven zijn beter geschikt om de bufferende interactie-effecten te toetsen. 


\section{Onderzoeksmodel en hypothesen}

De volle pijlen in het onderzoeksmodel (figuur 1) verwijzen naar de veronderstelde hoofdeffecten, de gearceerde pijlen naar de veronderstelde interactie-effecten. Het additieve model omvat alleen de hoofdeffecten, het multiplicatieve model zowel de hoofd- als interactie-effecten.

Figuur I Het onderzoeksmodel

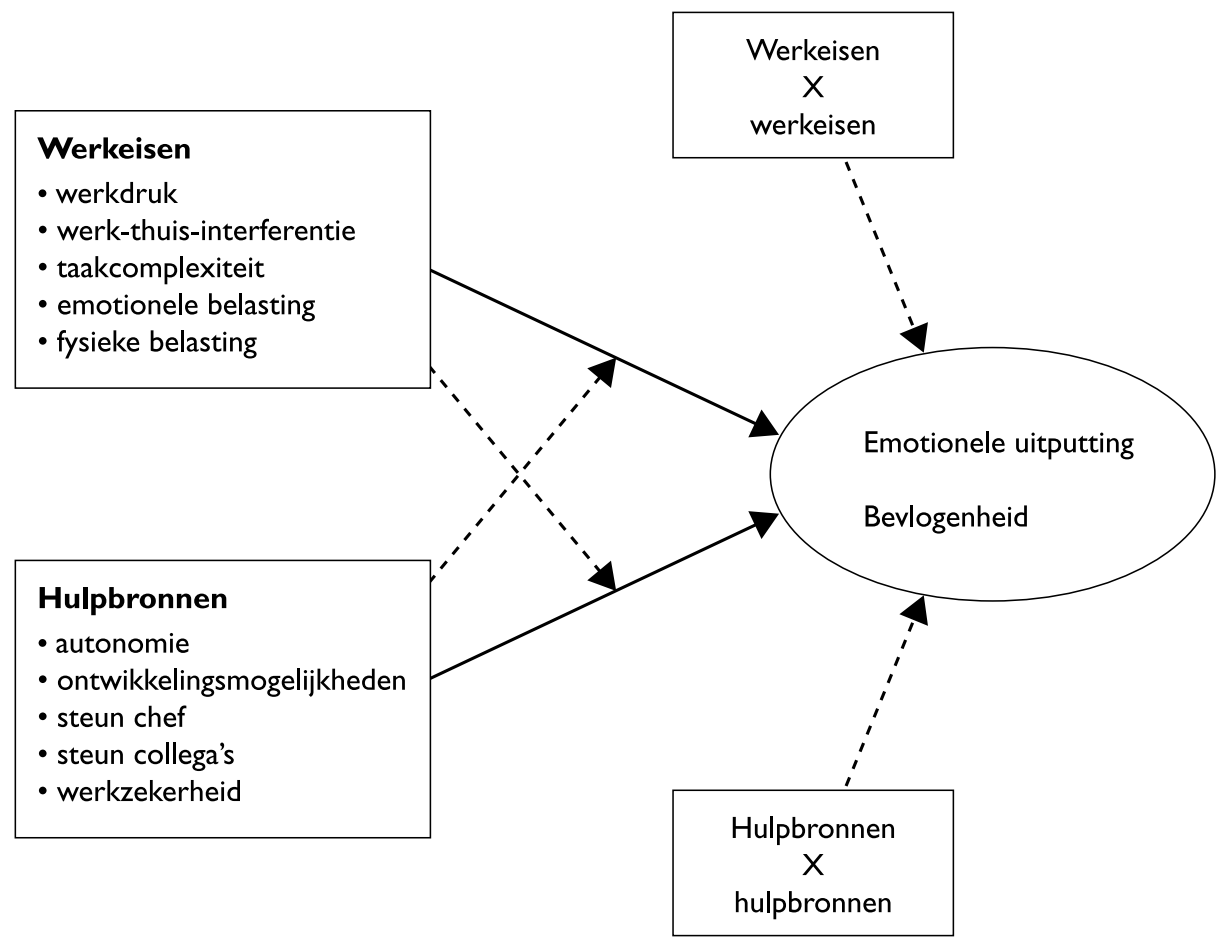

In het onderzoeksmodel zijn vijf werkeisen opgenomen: werkdruk, emotionele belasting, fysieke belasting, werk-thuis-interferentie (WTI) en taakcomplexiteit. Het JD-R-model voorspelt dat een toename in elk van deze werkeisen een toename van de emotionele uitputting en een afname van de bevlogenheid tot gevolg heeft. Studies naar de effecten van werkdruk, emotionele belasting, belastende arbeidsomstandigheden en WTI bevestigen de positieve samenhang met spanning en de negatieve samenhang met welbevinden (Demerouti et al., 2001; Schaufeli \& Bakker, 2004; Bakker et al., 2005; Van der Hulst, Van Veldhoven \& Beckers, 2006; Van Ruysseveldt, 2006).

Daarnaast zijn de volgende vijf hulpbronnen opgenomen: autonomie, steun van de chef, steun van collega's, ontwikkelingsmogelijkheden en werkzekerheid. Het JD-Rmodel voorspelt dat een toename in elk van deze hulpbronnen samenhangt met een afname in de uitputting en een toename van de bevlogenheid. De positieve effecten van deze werkkenmerken op het welbevinden van werknemers en de negatieve effecten op stress zijn in talrijke studies bevestigd (Karasek \& Theorell, 1990; Sosik \& Godshalk, 2000; Demerouti et al., 2001; Notelaers \& Van Veldhoven, 2001; Van Ruysseveldt, 
Cambré, Depickere \& Adiele, 2004; Bakker et al., 2005; Van der Hulst, Van Veldhoven \& Beckers, 2006; Van Ruysseveldt, 2006). We formuleren de volgende hypothesen:

H1a: De werkeisen hebben elk een significant positief hoofdeffect op emotionele uitputting.

H1b: De werkeisen hebben elk een significant negatief hoofdeffect op bevlogenheid.

H2a: De hulpbronnen hebben elk een significant negatief hoofdeffect op emotionele uitputting.

H2b: De hulpbronnen hebben elk een significant positief hoofdeffect op bevlogenheid.

In het onderzoeksmodel is verondersteld dat elke hulpbron het verband tussen elke werkeis en de werkuitkomsten modereert. Wanneer een specifieke hulpbron in hoge mate aanwezig is, heeft dat hypothetisch tot gevolg dat de negatieve effecten van een specifieke werkeis sterk verminderen of verdwijnen (Karasek \& Theorell, 1990; Zijlstra, Den Hoedt \& De Vries, 2000; Bakker et al., 2005; Van der Hulst, Van Veldhoven \& Beckers, 2006; Van Ruysseveldt, 2006). In een meta-analyse van 63 studies vinden Van der Doef en Maes (1999) slechts gedeeltelijk steun voor de bufferhypothese. En in een onderzoek naar werkstress in Nederland en Vlaanderen vinden Notelaers en Van Veldhoven (2001: 92) geen interactie-effect van autonomie op de relatie tussen werkdruk en psychische vermoeidheid. In ander onderzoek (Bakker et al., 2005; Xanthopoulou et al., 2007) is wel empirisch bewijs gevonden voor de plausibiliteit van de bufferhypothese. Om deze plausibiliteit verder te testen, toetsen we de volgende hypothesen:

H3a: Elk van de hulpbronnen heeft een significant modererend effect op de relatie tussen elk van de werkeisen en emotionele uitputting.

H3b: Elk van de werkeisen heeft een significant modererend effect op de relatie tussen elk van de hulpbronnen en bevlogenheid.

In de hier uitgevoerde multiplicatieve analyse zijn daarnaast ook de interacties tussen de werkeisen onderling en tussen de hulpbronnen onderling opgenomen. De veronderstelling daarbij is dat wanneer in het werk meerdere werkeisen tezelfdertijd in hoge mate voorkomen, hun gezamenlijk effect op uitputting en bevlogenheid groter is dan de optelsom van elk van hun afzonderlijke effecten. Hun gezamenlijke effect is het resultaat van een multiplicatieve (in tegenstelling tot een additieve) functie. We noemen dit de versterkingshypothese. In theoretisch opzicht is dat versterkend effect als volgt te onderbouwen. Het JD-R-model is in wezen een balansmodel. Wanneer een werkeis een hoog niveau bereikt, kan de werknemer het effect ervan compenseren door het inzetten van hulpbronnen. Deze veronderstelling is in overeenstemming met de Conservation-of-Resources-Theory (COR) van Hobfoll (2002), een van de theoretische fundamenten waarop het JD-R-model steunt. Voor Hobfoll (2002: 307) zijn met resources of hulpbronnen onder andere de volgende twee assumpties verbonden: (1) personen investeren in het verwerven van hulpbronnen omdat deze hen in staat stellen om te gaan met bedreigende omstandigheden en hen beschermen tegen de negatieve effecten van die omstandigheden, en (2) personen streven ernaar hun hulpbronnen niet alleen te beschermen, maar ook nieuwe te accumuleren (Hobfoll, 2002: 312). De eerste as- 
sumptie leidt tot de formulering van het derde mechanisme van resources (Hobfoll, 2002: 318): personen met veel hulpbronnen zijn beter in staat problemen verbonden met stressvolle gebeurtenissen op te lossen of te ondervangen, aangezien de kans toeneemt dat zij over de meest geëigende resources beschikken om de gestelde problemen op te lossen, of over resources beschikken die hen in staat stellen de benodigde resources te verwerven.

Bij een merkbare toename in een van de werkeisen kan de werknemer de uitputtingseffecten beperken door het inzetten van hulpbronnen (balansprincipe). Wanneer echter meerdere werkeisen tegelijk een problematisch niveau bereiken, geeft dat aanleiding tot een versnelde uitputting van de hulpbronnen en als gevolg hiervan tot een versnelde aantasting van de energiereserves. Bij een dreigende uitputting van de hulpbronnen neemt de kans toe dat voor geen enkele van de problematische werkeisen bevredigende oplossingen gevonden worden. Ook tot dan toe niet-problematische werkeisen raken 'geïnfecteerd' (spill-over-effect). Bijvoorbeeld: een werknemer wordt frequent geconfronteerd met lastige klanten die hem/haar onheus behandelen (emotionele belasting). Als gevolg daarvan loopt hij/zij een achterstand in het werk op (toenemende werkdruk) en komt de afstemming tussen werk en persoonlijke levenssfeer (WTI) in het gedrang. Uiteindelijk belandt hij/zij in een neerwaartse spiraal, waarbij op den duur de beschikbare hulpbronnen uitgeput geraken (resource depletion) en de gevolgen op zijn/haar welzijn veel omvangrijker zijn dan de afzonderlijke gevolgen van elk van de problematische werkeisen apart.

Hetzelfde versterkende interactie-effect - maar dan in positieve zin - veronderstellen we aan de zijde van de hulpbronnen. Wanneer in het werk tezelfdertijd meerdere hulpbronnen in hoge mate beschikbaar zijn, is het gezamenlijke effect op uitputting en bevlogenheid sterker dan de optelsom van elk van de afzonderlijke hoofdeffecten. Ook bij de hulpbronnen treedt een spill-over mechanisme in werking. Werknemers die over meer autonomie beschikken, kunnen deze benutten om meer ontwikkelingsmogelijkheden te verwerven, en omgekeerd. Er ontstaat een positieve spiraal van accumulatie van hulpbronnen, waardoor de werknemer beter in staat is het niveau van de werkeisen en de energieverslindende gevolgen van te hoge werkeisen te beheersen. Deze veronderstelling is in overeenstemming met Hobfolls (2002: 318) 'vijfde' mechanisme van resource: hulpbronnen zijn met elkaar verbonden, in die zin dat er een tendens bestaat om de beschikbare hulpbronnen te benutten voor het verwerven van nieuwe, zodat de werknemer uiteindelijk resource caravans opbouwt.

De beslissing om ook interacties tussen werkeisen onderling en hulpbronnen onderling op te nemen is mede gebaseerd op inzichten uit eerder onderzoek op een representatieve steekproef uit de Vlaamse beroepsbevolking. Daaruit is een significant interactieeffect gevonden van leermogelijkheden en autonomie op psychische vermoeidheid en een significant en opmerkelijk sterk interactie-effect van leermogelijkheden en autonomie op plezier in het werk (Van Ruysseveldt, 2006: 339-340).

H4: De relatie tussen een werkeis en emotionele uitputting/bevlogenheid wordt significant gemodereerd door elk van de andere werkeisen.

H5: De relatie tussen een hulpbron en emotionele uitputting/bevlogenheid wordt significant gemodereerd door elk van de andere hulpbronnen. 
Het toetsen van een uitgebreid multiplicatief model (bij 10 werkkenmerken zijn er 45 interactietermen) als in dit onderzoek, staat onvermijdelijk bloot aan de kritiek dat op 'goed geluk' of op 'kanskapitalisatie-achtige' wijze naar significante interactietermen wordt gezocht. Zeker bij een grote steekproef is de kans reëel dat alleen al bij toeval 2 tot 4 significante interactietermen worden gevonden. Ten eerste vangen we deze kritiek ten dele op door alle interactietermen tegelijk in het model op te nemen en niet een afzonderlijk model per interactieterm te toetsen, zoals dat doorgaans gebeurt (zie Bakker et al., 2005; Xanthopoulou et al., 2007). Het gaat er ons niet zozeer om zo veel mogelijk significante interacties te vinden, maar wel die interacties op te sporen die een sterk modererend effect hebben, dat wil zeggen: voldoende krachtige voorspellers zijn.

Ten tweede is nog een alternatieve toetsing uitgevoerd. In navolging van het DISCmodel (De Jonge \& Dormann, 2006) zijn de tien werkkenmerken ondergebracht in de categorieën 'cognitief' (werkdruk, taakcomplexiteit, WTI, autonomie en ontwikkelingsmogelijkheden), 'emotioneel' (emotionele belasting, steun leiding en steun collega's) en 'fysiek' (fysieke belasting). Volgens het matching principle van het DISC-model zal het effect van cognitieve werkeisen op cognitieve werkuitkomsten vooral worden gedempt door de cognitieve hulpbronnen, en het effect van emotionele werkeisen op emotionele werkuitkomsten vooral worden gedempt door de emotionele hulpbronnen. Door onze tien werkkenmerken in de drie categorieën onder te brengen en alleen interactietermen te berekenen binnen elke categorie en niet tussen de categorieën, daalt het aantal interactietermen in het model van 45 naar 15 (WTI is ook gecombineerd met de emotionele hulpbronnen). De resultaten van deze alternatieve toetsing zijn vervolgens vergeleken met die van het model met alle interactietermen.

\section{Methode}

\section{Dataverzameling en steekproef}

De TNO Arbeidssituatie Survey (TAS) is een schriftelijke cross-sectionele survey die iedere twee jaar de arbeidssituatie in een random steekproef van de Nederlandse beroepsbevolking meet (Smulders et al., 2001). Omdat vrouwen en jongeren ondervertegenwoordigd waren, is een aanvullende steekproeftrekking gedaan bij deze groepen (Evers, Ybema \& Smulders, 2006: 42). In 2002 omvatte de nettosteekproef 4009 personen (respons van $45 \%$ ).

\section{Meetinstrumenten}

Emotionele uitputting is gemeten aan de hand van de vijf items van de Utrechtse Burnout Schaal UBOS (Schaufeli \& Van Dierendonk, 2000). Een voorbeeld van een item is: 'Aan het einde van een werkdag voel ik me leeg'. Antwoorden kan op een zevenpuntsschaal gaande van 'nooit' tot 'dagelijks'. Deze schaal heeft een interne consistentie (Cronbachs alpha) van 0.89 .

Bevlogenheid is gemeten aan de hand van tien items (een ingekorte versie van de Utrechtse Bevlogenheidsschaal UBES; Schaufeli \& Bakker, 2004). Een voorbeeld van een item is: 'Op mijn werk bruis ik van energie'. Antwoorden kan op een zevenpunts- 
schaal gaande van 'nooit' tot 'dagelijks'. Deze schaal heeft een interne consistentie (Cronbachs alpha) van 0.92 .

De werkkenmerken zijn gemeten op vierpuntsschalen variërend van 'nooit' (1) tot 'altijd' (4) (zie Smulders et al., 2001).

Werkdruk is gemeten met vijf items die een indicatie geven van de kwantitatieve werkdruk. Een voorbeelditem is: 'Moet u erg snel werken?'. Deze werkdrukschaal heeft een interne consistentie (Cronbachs alpha) van 0.82.

Taakcomplexiteit meet aan de hand van vijf items de kwalitatieve werkdruk, meer bepaald het beslag dat het werk geestelijk legt op de werknemer. De vragen zijn ontleend aan Houtman, Goudswaard, Dhondt, Van der Grinten, Hildebrandt \& Kompier (1995). Een voorbeelditem is: 'Vereist uw werk intensief nadenken?'. Deze complexiteitsschaal heeft een interne consistentie van 0.81 .

Emotionele belasting is gemeten met drie items die een indicatie geven van de mate waarin de taakuitvoerder emotioneel belastend werk moet verrichten. Een voorbeelditem is: 'Vereist uw werk dat u zich opgewekt en opgeruimd gedraagt?'. Deze werkdrukschaal heeft een interne consistentie (Cronbachs alpha) van 0.86 .

Voor de werkeis werk-thuis-interferentie (WTI) is, wegens het ontbreken van een schaal, gebruikgemaakt van het item: 'Mist of verwaarloost $u$ familie- of gezinsactiviteiten door uw werk?'. Antwoorden kan op een vierpuntsschaal variërend van 'nee, nooit' (1) tot 'ja, zeer vaak' (4).

Autonomie in het werk is gemeten aan de hand van vijf items die een variant zijn op de decision latitude-vragen uit de Job Content Questionnaire van Karasek. Ze zijn bewerkt en vertaald door Goudswaard, Dhondt \& Kraan (1998). Een voorbeelditem is: 'Kunt u zelf beslissen hoe u uw werk uitvoert?'. Deze autonomieschaal heeft een interne consistentie van 0.86 .

De ontwikkelingsmogelijkheden zijn gemeten met vijf items die de mate indiceren waarin het werk aansluit bij ontwikkelde kennis en vaardigheden en de mate waarin de taakuitvoerder wordt geprikkeld om zich in het werk verder te ontwikkelen (cfr. skill discretion bij Karasek) (Houtman et al., 1995; Goudswaard et al., 1998). Een voorbeeld van een item is: 'Vereist uw baan dat u nieuwe dingen leert?'. Deze schaal heeft een interne consistentie van 0.80 .

De steun van de chef en van de collega's is telkens gemeten met vier items, die ontleend zijn aan de Job Content Questionnaire van Karasek (Houtman et al., 1995; Smulders et al., 2001). Een voorbeelditem van steun van de chef is: 'Mijn chef heeft oog voor het welzijn van de medewerkers'. Deze schaal heeft een interne consistentie van 0.83. Een voorbeelditem van steun van de collega's is: 'Mijn collega's helpen om het werk gedaan te krijgen'. Deze schaal heeft een interne consistentie van 0.78 .

Werkzekerheid is gemeten met drie items die ontleend zijn aan Goudswaard et al. (1998). Een voorbeeld van een item is: 'Maakt u zich zorgen over het behoud van uw baan?'. Deze schaal heeft een interne consistentie van 0.85 . 


\section{Sociaaldemografische kenmerken}

In de statistische analyses is steeds gecontroleerd voor vier sociaaldemografische kenmerken: geslacht, leeftijd, onderwijsniveau en wekelijkse arbeidsduur (contracturen).

\section{Resultaten}

De analyses zijn uitgevoerd aan de hand van het statistische verwerkingprogramma SPSS. Voor het toetsen van de hypothesen is gebruikgemaakt van hiërarchische regressieanalyse. Eerst is de betrouwbaarheid van de gebruikte schalen onderzocht. Met uitzondering van de schaal steun collega's (.78) bedraagt de Cronbachs alpha van de schalen .80 of meer. De betrouwbaarheid van de gehanteerde schalen is daarmee goed tot zeer goed te noemen.

In tabel 1 zijn de resultaten van de hiërarchische regressieanalyse voor de afhankelijke variabele emotionele uitputting gerapporteerd. In de tweede kolom zijn de regressiecoëfficiënten bij model 1, het additieve model, opgenomen. Dat model omvat naast de controlevariabelen alleen de hoofdeffecten van de vijf werkeisen en de vijf hulpbronnen. In de derde kolom staan de resultaten vermeld van de toetsing van het multiplicatieve model. Naast de hoofdeffecten zijn in model 2 ook alle interacties tussen werkeisen en hulpbronnen, tussen werkeisen onderling en tussen hulpbronnen onderling opgenomen. Om problemen met multicollineariteit te vermijden zijn de interactietermen berekend door de gestandaardiseerde schaalscores van de betreffende variabelen te vermenigvuldigen.

Een eerste vaststelling is dat de hoofdeffecten uit model 1 en 2 onderling nauwelijks verschillen vertonen op het vlak van het significantieniveau, de grootte en de richting van de regressiecoëfficiënten. Alleen de schaal taakcomplexiteit kent in het multiplicatieve model een hogere significantie $(\mathrm{p}<.01)$ dan in het additieve model $(\mathrm{p}<.05)$. Alle andere werkkenmerken hebben in beide modellen hoofdeffecten op een significantieniveau $\mathrm{p}<.01$. Het additieve model genereert een totale verklaarde variantie (Adj. R2) van $23 \%$. Voor het multiplicatieve model bedraagt de totale verklaarde variantie $26 \%$, een eerder lichte toename. De werkeisen leveren de grootste bijdrage in de verklaarde variantie $\left(\Delta R^{2}=.15\right)$, wat conform een van de kernassumpties van het JD-R-model is (Demerouti et al., 2001: 499), maar de bijdrage van de vijf hulpbronnen $\left(\Delta \mathrm{R}^{2}=.07\right)$ valt niet te verwaarlozen.

Elk van de vijf werkeisen heeft een significant positief hoofdeffect op emotionele uitputting ( $\mathrm{H} 1 \mathrm{a})$. Bovendien is de richting van de gevonden verbanden zoals verwacht. Een toename in werkdruk, emotionele belasting, fysieke belasting, WTI en taakcomplexiteit hangt samen met een significante toename in de emotionele uitputting. Vooral werkdruk $(~(=, 23)$ en WTI $(\beta=.13)$ blijken krachtige voorspellers van uitputting. 
Tabel I Hiërarchische multipele regressieanalyse met emotionele uitputting als afhankelijke variabelen (TAS 2002) ${ }^{a}$

\begin{tabular}{|c|c|c|}
\hline & \multicolumn{2}{|c|}{ Emotionele uitputting } \\
\hline & Additief model & Multiplicatief model \\
\hline Onderwijsniveau & $.05^{* *}$ & $.05 * *$ \\
\hline Leeftijd & $.05^{* *}$ & $.05^{* *}$ \\
\hline Aantal contracturen & $.06 * *$ & $.07 * *$ \\
\hline Geslacht & ns & ns \\
\hline Werkdruk & $.24^{* *}$ & .23 ** \\
\hline WTI & $.14^{* *}$ & $.13 * *$ \\
\hline Fysieke belasting & $.10^{* *}$ & $.10^{* *}$ \\
\hline Emotionele belasting & $.09 * *$ & $.09 * *$ \\
\hline Taakcomplexiteit & $.05 *$ & $.06 * *$ \\
\hline Autonomie & $.05 * *$ & $.06 * *$ \\
\hline Ontwikkelingsmogelijkheden & $.09 * *$ & $.10 * *$ \\
\hline Werkzekerheid & $.13^{* *}$ & $.13^{* * *}$ \\
\hline Steun chef & $.12^{* *}$ & $.12^{* *}$ \\
\hline Steun collega's & $.07^{* *}$ & $.06 * *$ \\
\hline \multicolumn{3}{|l|}{ Interacties werkeisen $\mathrm{x}$ hulpmiddelen ${ }^{\mathrm{a}}$} \\
\hline WTI $x$ steun collega's & & $.04 *$ \\
\hline WTI $x$ werkzekerheid & & $.06 * *$ \\
\hline Emotionele belasting $\times$ steun chef & & $.06 * *$ \\
\hline \multicolumn{3}{|l|}{$\begin{array}{l}\text { Interacties werkeisen onderling en } \\
\text { hulpmiddelen onderling }\end{array}$} \\
\hline Werkdruk $x$ taakcomplexiteit & & $.09 * *$ \\
\hline WTI x fysieke belasting & & $.04 *$ \\
\hline Autonomie $\mathrm{x}$ steun chef & & $.04^{*}$ \\
\hline Ontwikkelingsmogelijkheden $\mathrm{x}$ steun chef & & $.06 * *$ \\
\hline $\begin{array}{l}\text { Ontwikkelingsmogelijkheden x steun } \\
\text { collega's }\end{array}$ & & $.04 *$ \\
\hline Constante & 2.66 & 2.61 \\
\hline Model & $93.86 * *$ & $25.96 * *$ \\
\hline $\begin{array}{l}\text { Totaal verklaarde variantie (Adj. } R \\
\text { kwadraat) }\end{array}$ & .23 & .26 \\
\hline
\end{tabular}

${ }^{a}$ Alleen de significante interactietermen zijn in de tabel opgenomen.

$* * \mathrm{p}<.01 ; * \mathrm{p}<.05$.

Elk van de vijf hulpbronnen heeft een significant negatief hoofdeffect op emotionele uitputting (H2a). Bovendien is de richting van de gevonden verbanden conform de verwachtingen. Een gebrek aan autonomie, aan ontwikkelingsmogelijkheden, aan steun van de chef en de collega's en aan werkzekerheid leidt tot een significante toename van de emotionele uitputting. Gebrek aan werkzekerheid ( $(=-.13)$ en steun van de chef $(\Omega=-.12)$ zijn bij de hulpbronnen de krachtigste voorspellers van uitputting.

Slechts drie van de 25 veronderstelde interactie-effecten tussen werkeisen en hulpbronnen blijken significant, en samen voegen deze interactietermen $2 \%$ toe aan de totale verklaarde variantie. In drie gevallen buffert een hulpbron het effect van een werkeis op emotionele uitputting (H3a), wat betekent dat in de conditie dat zowel die werkeis als die hulpbron in hoge mate aanwezig is, het niveau van emotionele uitputting lager ligt dan in de conditie waarin die werkeis wel en die hulpbron niet in hoge mate aanwezig 
is. Zo heeft bij een hoge en problematische werk-thuis-interferentie meer steun van collega's tot gevolg dat het positieve effect van WTI op emotionele uitputting verdwijnt. Bovendien stijgt de emotionele uitputting aanzienlijk naarmate een hoge en problematische werk-thuis-interferentie gepaard gaat met een werksituatie waarin de werknemer weinig steun aan zijn of haar collega's heeft. Bij de werkeis emotionele belasting vermindert de steun van de chef op een significante wijze het effect op emotionele uitputting. Naarmate in een werksituatie met een hoge emotionele belasting de chef veel steun verleent aan de werknemer, stijgt diens emotionele uitputting aanzienlijk minder dan wanneer de chef weinig steun geeft.

In model 2 zijn ook de interacties tussen de werkeisen onderling en tussen de hulpbronnen onderling opgenomen. Het valt op dat vijf van de 20 veronderstelde interactietermen significant zijn (H4 en H5). De veronderstelling luidt dat werkeisen elkaars positieve effect op uitputting versterken en dat hulpbronnen elkaars negatieve effect op uitputting versterken. Zo blijkt uit tabel 1 dat een toename van de werkdruk een stijging in het niveau van emotionele uitputting tot gevolg heeft, maar dat dit effect veel sterker is wanneer het werk tezelfdertijd in hoge mate complex is. Hetzelfde versterkende effect treedt op bij combinaties van een hoog problematische WTI en een hoge fysieke belasting.

Wat de interacties tussen hulpbronnen betreft, blijkt dat de steun van de chef het effect van twee andere hulpbronnen op uitputting versterkt: veel autonomie en ontwikkelingsmogelijkheden hebben een lager niveau van uitputting tot gevolg naarmate de werknemer meer steun heeft aan zijn of haar chef. Voor de hulpbron ontwikkelingsmogelijkheden heeft ook de steun van de collega's een dergelijk versterkend effect. Blijkbaar benutten werknemers de beschikbare ontwikkelingsmogelijkheden meer of beter naarmate op de werkvloer een beter sociaal klimaat heerst, in de zin van meer steun van chef en collega's.

In tabel 2 zijn de resultaten van de regressieanalyse met bevlogenheid als afhankelijke variabele weergegeven. Ook hier is de eerste vaststelling dat de hoofdeffecten tussen model 1 en 2 onderling nauwelijks verschillen vertonen. In vergelijking met de analyse met emotionele uitputting als afhankelijke variabele ligt de totale verklaarde variantie hoger (Adj. $\mathrm{R}^{2}=.37$ voor het additieve model; .39 voor het multiplicatieve model), terwijl die verklaarde variantie in het geval van bevlogenheid door minder werkkenmerken wordt gegenereerd. Slechts zes van de tien veronderstelde hoofdeffecten zijn significant $(\mathrm{p}<.01)$. Van de werkeisen heeft alleen de taakcomplexiteit een significant hoofdeffect $(~(\beta=.11)$, waarbij de richting van het verband tegengesteld is aan de verwachtingen (zie H1b). Deze vaststelling doet vermoeden dat de taakcomplexiteit zich in geval van positieve werkuitkomsten eerder als een hulpbron dan als een werkeis 'gedraagt' (zie Karasek \& Theorell, 1990). De andere werkeisen hebben geen significant hoofdeffect op bevlogenheid. Daarmee bestaat voor de plausibiliteit van hypothese $1 \mathrm{~b}$ weinig empirisch bewijs. De hulpbronnen leveren de grootste bijdrage in de verklaarde variantie $\left(\Delta \mathrm{R}^{2}=.19\right)$, wat conform een van de kernassumpties van het JD-R-model is (Demerouti et al., 2001: 499), maar ook de bijdrage van de taakcomplexiteit $\left(\Delta \mathrm{R}^{2}=\right.$ .11) is belangrijk.

Onder de hulpbronnen blijken meer bepaald de ontwikkelingsmogelijkheden in het werk een krachtige voorspeller van bevlogenheid $(\beta=.36)$, aanzienlijk krachtiger dan de predictieve waarde van autonomie $(\beta=.12)$. 
Tabel 2 Hiërarchische multipele regressieanalyse met bevlogenheid als afhankelijke variabele (TAS 2002)

\begin{tabular}{|c|c|c|}
\hline & Bevlo & heid \\
\hline & Additief model & $\begin{array}{c}\text { Multiplicatief } \\
\text { model }\end{array}$ \\
\hline Onderwijsniveau & $-.09 * *$ & $-.09 * *$ \\
\hline Leeftijd & $.16 * *$ & $.16^{* *}$ \\
\hline Aantal contracturen & $-.06 * *$ & $-.07^{* *}$ \\
\hline Geslacht & ns & ns \\
\hline Werkdruk & ns & ns \\
\hline WTI & ns & ns \\
\hline Fysieke belasting & ns & ns \\
\hline Emotionele belasting & ns & ns \\
\hline Taakcomplexiteit & $.12^{* *}$ & $.11 * *$ \\
\hline Autonomie & $.12 * *$ & $.12 * *$ \\
\hline Ontwikkelingsmogelijkheden & $.36 * *$ & $.36 * *$ \\
\hline Werkzekerheid & $.08 * *$ & $.08^{* *}$ \\
\hline Steun chef & $.14 * *$ & $.14^{* *}$ \\
\hline Steun collega's & $.12^{* *}$ & $.12^{* * *}$ \\
\hline Interacties werkeisen $x$ hulpmiddelen ${ }^{a}$ & & \\
\hline WTI $\times$ autonomie & & $.03 *$ \\
\hline Fysieke belasting $\mathrm{x}$ autonomie & & $-.05^{* *}$ \\
\hline Fysieke belasting $\mathrm{x}$ steun collega's & & $.05 * *$ \\
\hline Emotionele belasting $\mathrm{x}$ ontwikkelingsmogelijkheden & & $.05 *$ \\
\hline $\begin{array}{l}\text { Interacties werkeisen onderling en hulpmidd } \\
\text { onderling }^{\text {a }}\end{array}$ & & \\
\hline Werkdruk x WTI & & $.04 *$ \\
\hline Werkdruk $\mathrm{x}$ taakcomplexiteit & & $-.05^{*}$ \\
\hline Autonomie $\mathrm{x}$ ontwikkelingsmogelijkheden & & $-.08^{* *}$ \\
\hline Autonomie $\mathrm{x}$ steun collega's & & $.04 *$ \\
\hline Constante & $3.43 * *$ & $3.44 *$ \\
\hline Model & $130.77^{* *}$ & $33.51 * *$ \\
\hline Totaal verklaarde variantie (Adj. R kwadraat) & .37 & .39 \\
\hline
\end{tabular}

${ }^{a}$ Alleen de significante interactietermen zijn in de tabel opgenomen.

$* * p<.01$ of minder; $* p<.05$ of minder

Van de 25 veronderstelde interactietermen tussen werkeisen en hulpbronnen zijn er vier significant. Zo heeft een hoog problematische werk-thuis-interferentie alleen een geringere bevlogenheid tot gevolg wanneer de autonomie in het werk gering is. Ook van de 20 veronderstelde interactietermen tussen werkeisen onderling en tussen hulpbronnen onderling zijn er vier significant. Zo heeft een hoge mate van autonomie een hoger niveau van bevlogenheid tot gevolg naarmate de werknemer over meer ontwikkelingsmogelijkheden beschikt, en naarmate hij of zij meer steun heeft van collega's. En bij een hoge werkdruk heeft de mate van taakcomplexiteit geen verdere invloed op de bevlogenheid, maar bij een lage werkdruk heeft een geringe taakcomplexiteit een aanzienlijke daling van de bevlogenheid tot gevolg. Samen voegen de acht significante interactietermen $2 \%$ toe aan de verklaarde variantie in bevlogenheid.

Zoals bij het formuleren van de hypothesen is aangegeven is tot slot nog een alternatieve toetsing uitgevoerd. Daarin zijn niet alle interacties tussen en binnen de werkeisen 
en hulpbronnen opgenomen, maar alleen tussen en binnen de werkeisen en hulpbronnen die op grond van het DISC-model tot dezelfde categorie behoren: cognitief, emotioneel en fysiek (De Jonge \& Dormann, 2006). In het alternatieve model is het aantal interactietermen gereduceerd van 45 naar 15 . De toetsingsresultaten van dit alternatieve model wijken niet substantieel af van die van het uitgebreide multiplicatieve model. In beide modellen zijn bijna alle dezelfde interactietermen significant dan wel insignificant. In het alternatieve model ontbreken uiteraard de interacties tussen de werkkenmerken die tot een verschillende categorie behoren, maar toch een significant en relatief sterk interactie-effect hebben. Het matching principle, alhoewel logisch beargumenteerbaar, gaat in de werkelijkheid niet steeds op: het effect van een emotionele werkeis (emotionele belasting) op bevlogenheid wordt wel gedempt door een cognitieve hulpbron (ontwikkelingsmogelijkheden), maar niet door de emotionele hulpbronnen. Deze vaststelling is in overeenstemming met de conclusies van Xanthopoulou et al. (2007: 781). Op grond van deze empirische aanwijzingen en het 'beperkende' karakter van het matching principle, opteren we voor het uitgebreide multiplicatieve model.

\section{Conclusies}

Uit ons onderzoek op een representatieve steekproef uit de Nederlandse beroepsbevolking zijn de volgende conclusies af te leiden. De werkeisen hebben elk een significant positief en de hulpbronnen elk een significant negatief hoofdeffect op uitputting (bevestiging van $\mathrm{H} 1 \mathrm{a}$ en $\mathrm{H} 2 \mathrm{a}$ ). Met een toename van de werkdruk, WTI, fysieke en emotionele belasting en de taakcomplexiteit, stijgt de emotionele uitputting. Naarmate de werknemer beschikt over meer autonomie, ontwikkelingsmogelijkheden, werkzekerheid en steun van chef en collega's, daalt de emotionele uitputting. Ook blijkt dat elk van de hulpbronnen een significant positief hoofdeffect heeft op bevlogenheid (bevestiging van H2b). De bevlogenheid in het werk wordt bevorderd door een hoge mate van autonomie, veel ontwikkelingsmogelijkheden, werkzekerheid en veel steun van chef en collega's.

De hypothese $1 \mathrm{~b}$ dient verworpen te worden. Het is opmerkelijk dat bij bevlogenheid nauwelijks significante hoofdeffecten van werkeisen optreden. Alleen taakcomplexiteit heeft een dergelijk effect, maar de richting is niet in overeenstemming met onze veronderstelling: er is geen negatief, maar een positief hoofdeffect gevonden. Dat doet vermoeden dat taakcomplexiteit zich ten aanzien van positieve werkuitkomsten zoals bevlogenheid 'gedraagt' als een hulpbron.

Het multiplicatieve model voegt in vergelijking met het additieve model niet bijzonder veel toe aan de totale verklaarde variantie $(+2,5 \%$ bij uitputting en $+1,3 \%$ bij bevlogenheid). Slechts een minderheid van de veronderstelde interactie-effecten is significant: acht bij uitputting en acht bij bevlogenheid, op een totaal van telkens 45 veronderstelde interactie-effecten. Deze onderzoeksresultaten geven geen voldoende empirisch bewijs voor de hypothesen $3 \mathrm{a}, 3 \mathrm{~b}, 4$ en 5 . Concreet vervult in drie (bij uitputting) en vier (bij bevlogenheid) gevallen een van de hulpbronnen een bufferende rol. Bij uitputting bufferen steun van de collega's en werkzekerheid het effect van WTI en steun van de chef het effect van emotionele belasting. Bij bevlogenheid buffert autonomie het effect van WTI én van fysieke belasting; steun van collega's buffert het effect van fysieke belasting, en ontwikkelingsmogelijkheden bufferen het effect van emotionele belasting. Steeds is het verloop van het interactie-effect conform de bufferhypothese. 
Opmerkelijk is ook de vaststelling dat de significante interacties tussen werkeisen onderling en tussen hulpbronnen onderling in termen van aantal, significantieniveau en predictieve waarde minstens even belangrijk zijn als de bufferende interacties. Bij uitputting zijn vijf van de 20 opgenomen interactietermen significant: combinaties van werkdruk en taakcomplexiteit en van WTI en fysieke belasting hebben gezamenlijk een sterker effect op uitputting dan de optelsom van hun afzonderlijke effecten. Bij de hulpbronnen blijken drie combinaties significant: autonomie en werkzekerheid, ontwikkelingsmogelijkheden en steun van de chef, en ontwikkelingsmogelijkheden en steun van collega's. Het verloop van het interactie-effect is conform de versterkingshypothese.

\section{Discussie}

Dit onderzoek tracht twee onderzoeksvragen te beantwoorden. (1) In welke mate zijn op basis van specifieke werkkenmerken verschillen in emotionele uitputting/bevlogenheid tussen Nederlandse werknemers te verklaren? (2) In welke mate biedt een multiplicatief onderzoeksmodel met veronderstelde interacties tussen alle werkkenmerken een meerwaarde boven een louter additief model?

De eerste onderzoeksvraag is hiervoor eenduidig beantwoord. De veronderstellingen ten aanzien van de hoofdeffecten, ontleend aan het JD-R-model, zijn grotendeels bevestigd. Niet conform de veronderstellingen is de vaststelling dat vier van de vijf werkeisen geen significant hoofdeffect hebben op bevlogenheid. Dit wijkt af van meerdere andere onderzoeken waarin wel een significant hoofdeffect van de werkeisen op de bevlogenheid is gevonden (Bakker \& Demerouti, 2007). Bovendien heeft de vijfde werkeis, taakcomplexiteit, wel een significant hoofdeffect, maar dan een positief in plaats van het verwachte negatieve. Taakcomplexiteit 'gedraagt' zich in de analyse als een hulpbron. Blijkbaar zijn niet alle werkkenmerken exclusief in een van de twee categorieën in te delen. Daarmee is de strikte onderverdeling van werkkenmerken in de categorieën werkeisen en hulpbronnen in vraag gesteld.

Onze tweede onderzoeksvraag is minder eenduidig te beantwoorden. De meerwaarde van het multiplicatieve model in vergelijking met het additieve model is op het eerste gezicht erg gering te noemen. De toevoeging van interactietermen leidt in geen van de analyses tot een belangrijke verhoging van de totale verklaarde variantie. $\mathrm{Nu}$ mag dit niet het enige criterium zijn bij de beoordeling van de plausibiliteit van het multiplicatieve model. McClelland \& Judd (1993: 377) benadrukken dat in veldonderzoek interactie-effecten zelden bijdragen tot een aanzienlijke verhoging van de verklaarde variantie, zodat een verhoging van $1 \%$ reeds als belangrijk bestempeld moet worden. Vanuit een dergelijk standpunt blijft de aandacht voor interactie-effecten tussen werkkenmerken - gezien onze analyseresultaten - verdedigbaar. In elke toetsing zijn enkele significante interactie-effecten gevonden. Sommige daarvan ondersteunen de bufferhypothese, andere de versterkingshypothese. Inderdaad valt op dat er ook significante interactie-effecten tussen werkeisen onderling en tussen hulpbronnen onderling voorkomen. Terwijl in het stressonderzoek veel aandacht en energie is besteed aan het theoretiseren en onderzoeken van de bufferhypothese, lijken deze vaststellingen te suggereren dat nader onderzoek - en ook theoretisch denkwerk - naar de versterkingshypothese zinvol is. Het is mogelijk dat naast de afzonderlijke effecten van werkeisen en hulpbronnen, juist ook specifieke combinaties van werkeisen bijkomende, aanzienlijk 
energieopslorpende effecten en specifieke combinaties van hulpbronnen bijkomende, aanzienlijk bevlogenheidverhogende effecten sorteren.

Een belangrijke kanttekening bij het vorenstaande is dat we een aanzienlijk lagere proportie significante interactie-effecten vinden dan bijvoorbeeld Bakker et al. (2005) en Xanthopoulou et al. (2007). Een mogelijke verklaring daarvoor is de wijze van analyseren. Wij hebben ervoor gekozen alle interactietermen samen in het model op te nemen, en niet - zoals de genoemde onderzoekers - per interactieterm een afzonderlijk model te toetsen. Bij die laatste aanpak van de analyse hadden ook wij meer significante interactie-effecten gevonden. Maar het was ons minder te doen om het aantal dan om het opsporen van voldoende krachtige voorspellende interactie-effecten. Toch blijft de vraag in welke mate de in ons onderzoek gevonden significante interactie-effecten berusten op statistisch toeval, dan wel een weerspiegeling zijn van de werkelijkheid. In welke mate kent het hier getoetste multiplicatieve model een voldoende robuust karakter? Er zijn indicaties dat hier enige voorzichtigheid geboden is. Bij een overschrijdingskans van $\mathrm{p}>.05$ zijn louter op grond van statistisch toeval ongeveer vier significante interactie-effecten te verwachten. Het aantal significante interactie-effecten in onze analyses ligt daarboven, maar is niet aanzienlijk hoger. Gezien de omvang van onze steekproef is niet uit te sluiten dat we de significante interactie-effecten op goed geluk hebben gevonden. Alvorens overheidsbeleid of interventies op organisatie- en werkplekniveau op deze resultaten te enten, is het noodzakelijk een beter zicht te krijgen op de stabiliteit van de bevindingen door hertoetsing van het multiplicatieve model op andere, vergelijkbare steekproeven. Bij een eerste, verkennende vergelijking tussen de hier gerapporteerde resultaten en die van de toetsing van een vergelijkbaar model op een Vlaamse steekproef van werknemers (Van Ruysseveldt, 2006) vallen alvast verschillen op. Zo blijkt in de Vlaamse steekproef autonomie een buffer te vormen tegen de uitputtingseffecten van hoge werkdruk en blijken leermogelijkheden het uitputtingsreducerende effect van hoge autonomie te versterken. Geen van beide interactie-effecten zijn in het onderzoek op de Nederlandse steekproef teruggevonden. In vervolgonderzoek zal nader worden onderzocht in welke mate de significante interactie-effecten stabiel zijn in de tijd en tussen landen.

Dit onderzoek kent uiteraard nog andere belangrijke beperkingen. Er is gebruikgemaakt van zelfgerapporteerde oordelen van werknemers over hun werk en omdat het onderzoeksdesign cross-sectioneel van aard is, kunnen uit de gevonden samenhangen geen conclusies met betrekking tot eventuele oorzakelijke verbanden getrokken worden. Verder longitudinaal (of quasi-experimenteel) onderzoek is vereist om te bepalen in welke mate het optreden of reduceren van risico's en de aan- of afwezigheid van hulpmiddelen in de tijd leiden tot het ontstaan of terugdringen van spannings- en welzijnsproblemen bij werknemers.

\section{Beleidsmatige implicaties}

De maatschappelijke en menselijke kostprijs van arbeidsuitval, bijvoorbeeld als gevolg van arbeidsongeschiktheid, is aanzienlijk. Ook trachten organisaties de kosten van onder meer ziekteverzuim en verloop onder controle te houden. Samenleving, organisaties en burgers hebben belang bij het verwerven van een zo goed mogelijk inzicht in de werkgerelateerde mechanismen die tot uitputting en bevlogenheid bij werknemers en daarmee samenhangend arbeidsongeschiktheid, ziekteverzuim en verloop leiden. 
Onze resultaten tonen aan dat uitputtingsverschijnselen bij werknemers vooral te relateren zijn aan hoge werkdruk en een problematische afstemming tussen werk en privésfeer. Maar ook een geringe werkzekerheid, gebrek aan ontwikkelingsmogelijkheden en weinig ondersteuning vanuit de leiding bevorderen het risico op uitputting. Algemene, landelijke streefdoelen en maatregelen op deze domeinen verdienen aandacht. Organisaties kunnen de bevlogenheid bij hun werknemers dan weer vooral stimuleren door hen meer hulpbronnen beschikbaar te stellen.

Ook is verder onderzoek naar de bufferende dan wel versterkende interactie-effecten vanuit beleidsmatig opzicht relevant. De huidige stand van het onderzoek bevestigt dat gezondheidsbedreigende spanningsklachten vooral opduiken in het kielzog van te hoge werkeisen (Demerouti et al., 2001; Bakker \& Demerouti, 2007). Vanuit beleidsen interventieperspectief is op grond hiervan te verdedigen om vooral maatregelen te treffen in de sfeer van deze werkeisen: werkdrukverlaging, betere afstemmingsmogelijkheden tussen werk en privésfeer, enzovoort. Nu is een dergelijke reductie of herontwerp van werkeisen op korte termijn niet altijd realiseerbaar, bijvoorbeeld bij gebrek aan financiële middelen voor een uitbreiding van de personeelsbezetting (Xanthopoulou et al., 2007). Als gevolg daarvan zou men het primaat kunnen leggen bij de hulpbronnen en hun bufferende werking: als werknemers maar over voldoende autonomie, leermogelijkheden, sociale steun en werkzekerheid beschikken, zullen ze wel in voldoende mate in staat zijn de uitputtingseffecten van te hoge werkeisen op te vangen. Denk in dit verband ook aan de interventiepraktijk gebaseerd op het JD-C-model van Karasek, die meer autonomie (regelmogelijkheden) als antistressremedie tegen te hoge werkdruk (regelproblemen) voorschrijft. Wordt soms niet als vanzelfsprekend (te) veel heil verwacht van de bufferende effecten van de hulpbronnen tegen te hoge werkeisen? Een dergelijke interventiestrategie is alleen verdedigbaar wanneer het buffermechanisme daadwerkelijk doet wat het geacht wordt te doen, voldoende krachtig is en optreedt in de meerderheid van de werkcontexten. Indien dat niet het geval is, blijft het dweilen met de kraan open. In die zin is het verantwoordbaar onderzoek te blijven doen naar het buffermechanisme, tot er voldoende empirische evidentie (pro of contra) beschikbaar is.

\section{Literatuur}

Bakker, A., Schaufeli, W. \& Demerouti, E. (1999). Werkstressoren, energiebronnen, en burnout: het WEB-model. In: J. Winnubst, F. Schuur \& J. Dam (red.). Praktijkboek gezond werken (pp.1-19). Maarssen: Elsevier.

Bakker, A. \& Geurts, S. (2004). Toward a Dual-Process Model of Work-Home Interference. Work and Occupations, 31, 345-366.

Bakker, A., Demerouti, E. \& Euwema, M. (2005). Job Resources Buffer the Impact of Job Demands on Burnout. Journal of Occupational Health Psychology, 10, 170-180.

Bakker, A. \& Demerouti, E. (2007). The Job Demands-Resources Model: state of the art. Journal of Managerial Psychology, 22, 309-328.

Blatter, B., Houtman, I., Bossche, S. van den, Kraan, K. \& Heuvel, S. van den (2005). Gezondheidsschade en kosten als gevolg van RSI en Psychosociale arbeidsbelasting in Nederland. Hoofddorp: TNO Kwaliteit van Leven (Onderzoek verricht in opdracht van het ministerie van SZW).

Demerouti, E., Nachreiner, F., Bakker, A. \& Schaufeli, W. (2001). The Job Demands-Resources Model of Burnout. Journal of Applied Psychology, 86, 499-512.

Doef, M. van der \& Maes, S. (1999). The Job Demand-Control(-Support) Model and psychological well-being: a review of 20 years of empirical research. Work \& Stress, 13, 87-114.

Evers, M., Ybema, J. \& Smulders, P. (2006). Arbeidstevredenheid: gevolg van werkkenmerken, werkwaarden of beide? Gedrag \& Organisatie, 19, 37-48. 
Goudswaard, A., Dhondt, S. \& Kraan, K. (1998). Flexibilisering en arbeid in de informatiemaatschappij; werknemersvragenlijst, bestemd voor werknemers en bedrijven die deelnemen aan het SZWWerkgeverspanel 1998. Hoofddorp: TNO Arbeid.

Hobfoll, S. (2002). Social and psychological resources and adaptation. Review of General Psychology, 6, 307-324.

Houtman, I., Goudswaard, A., Dhondt, S., Grinten, M. van der, Hildebrandt, V. \& Kompier, M. (1995). Evaluatie van de monitorstudie naar stress en lichamelijke belasting. Den Haag: VUGA.

Hulst, M. van der, Veldhoven, M. van \& Beckers, D. (2006). Overtime and need for recovery in relation to job demands and job control. Journal of Occupational Health, 48, 11-19.

Janssens, F. (2001). Kwaliteit van de arbeid: software of hardware? Over.werk, 4, 13-17.

Johnson, J., Hall, E. \& Theorell, T. (1989). Combined effects of job strain and social isolation on cardiovascular disease morbidity and mortality in a random sample of the Swedish male working population. Scandinavian Journal of Work, Environment, \& Health, 15, 271-279.

Jonge, J. de \& Dormann, C. (2006). Stressors, resources and strain at work: a longitudinal test of the triple match principle. Journal of Applied Psychology, 5, 1359-74.

Karasek, R. (1979). Job demands, job decision latitude, and mental strain: implications for job redesign. Administrative Science Quarterly, 24, 285-307.

Karasek, R. \& Theorell, T. (1990). Healthy work: stress, productivity and the reconstruction of working life. New York: Basic Books.

McClelland, G. \& Judd, C. (1993). Statistical difficulties of detecting interactions and moderator effects. Psychological Bulletin, 114, 376-390.

Notelaers, G. \& Veldhoven, M. van (2001). Psychosociale arbeidsbelasting en werkstress in Vlaanderen en Nederland. Een vergelijking tussen Vlaanderen en Nederland aan de hand van de VBBA. Enkele resultaten en bedenkingen. Verslagboek Arbeidsmarktonderzoekersdag 2001. Leuven: Acco.

Schaufeli, W. \& Dierendock, D. van (2000). UBOS - De Utrechtse Burnout Schaal. Handleiding. Lisse: Zwets \& Zeitlinger.

Schaufeli, W. \& Bakker, A. (2001). Werk en welbevinden. Naar een positieve benadering in de Arbeids- en gezondheidspsychologie. Gedrag en Organisatie, 14, 229-252.

Schaufeli, W. \& Bakker, A. (2004). Job demands, job resources, and their relationship with burnout and engagement: a multi-sample study. Journal of Organizational Behavior, 25, $293-$ 315.

Smulders, P. (2008). Balans van twee decennia kwaliteit van de arbeid. In: S. Dhondt \& F. Vaas. Waardevol werk; van arbeidskwaliteit naar sociale innovatie (pp. 87-99). Den Haag: Lemma.

Smulders, P., Andries, F. \& Otten, F. (2001). Hoe denken Nederlanders over hun werk? Opzet, kwaliteit en eerste resultaten van de TNO Arbeidssituatie Survey. Hoofddorp: TNO Arbeid.

Sosik, J. \& Godshalk, V. (2000). Leadership styles, mentoring functions received, and job-related stress: A conceptual model and preliminary study. Journal of Organizational Behavior, 21, 365-390.

Spector, P. \& Jex, S. (1998). Development of four self-report measures of job stressors and strain. Journal of Occupational Health Psychology, 3, 356-367.

Van Ruysseveldt, J., Cambré, B., Depickere, A. \& Adiele, M. (2004). Door de bank genomen? Stress in de banksector. In: G. Van Hootegem, \& B. Cambré (red.). Over werk $(t)$ in de actieve welvaartstaat (pp. 189-204). Leuven: Acco.

Van Ruysseveldt, J. (2006). Psychische vermoeidheid en plezier in het werk bij Vlaamse werknemers. Tijdschrift voor Arbeidsvraagstukken, 22, 328-343.

Veldhoven, M. van (1996). Psychosociale arbeidsbelasting en werkstress. Lisse: Swets \& Zeitlinger.

Veldhoven, M. van \& Meijman, T. (1994). Het meten van psychosociale arbeidsbelasting met een vragenlijst: de vragenlijst beleving en beoordeling van de arbeid (VBBA). Amsterdam: NIA.

Veldhoven, M. van, Meijman, T., Broersen, J. \& Fortuin, R. (2002). Handleiding VBBA. Amsterdam: SKB.

Veldhoven, M. van, Taris, T., Jonge, J. de \& Broersen, J. (2005). The relationship between work characteristics and employee health and well-being: how much complexity do we really need? International Journal of Stress Management, 1, 3-28.

Xanthopoulou, D., Bakker, A., Dollard, M., Demerouti, E., Schaufeli, W., Taris, T. \& Schreurs, P. (2007). When do job demands particularly predict burnout? The moderating role of job resources. Journal of Managerial Psychology, 8, 766-786.

Zijlstra, F., Hoedt, M. den \& Vries, R. de (2000). 'Job Control', hoe meer hoe beter? Gedrag en Organisatie, 13, 1-12. 